\title{
The effect of dietary protein source and guar gum on gastrointestinal growth and enteroglucagon secretion in the rat
}

\author{
BY SUSAN SOUTHON, JENNIFER M. GEE AND I. T. JOHNSON \\ AFRC Institute of Food Research, Norwich Laboratory, Colney Lane, Norwich NR4 $7 U A$
}

(Received 2 October 1986 - Accepted 11 March 1987)

\begin{abstract}
1. Male Wistar rats (approximately $100 \mathrm{~g}$ ) were given fibre-free semi-synthetic diets containing either casein or albumin $(168 \mathrm{~g} / \mathrm{kg} \mathrm{diet})$ as the protein source with or without guar gum ( $75 \mathrm{~g} / \mathrm{kg} \mathrm{diet}$ ) (casein, albumin, caseinguar gum and albumin-guar gum groups).

2. Small intestinal length, weights of caecal tissue and contents and plasma enteroglucagon concentration were significantly increased in guar-gum-fed animals compared with the fibre-free groups.

3. Total caecal weight and plasma enteroglucagon concentration were higher in the albumin-guar gum group compared with the casein-guar gum group. The weights of caecal tissue and contents were significantly increased in rats given the fibre-free albumin diet compared with those consuming a similar diet with casein as the protein source, although daily food intake tended to be lower.

4. It is concluded that the effect of materials classed as dietary fibre may be significantly influenced by the nonpolysaccharide component of the diet, and that such interactions may influence both the growth and endocrine activity of the gastrointestinal tract.
\end{abstract}

Dietary fibre was originally defined primarily as polysaccharides of plant cellular origin which are resistant to digestion by man (Southgate et al. 1978). However, in recent years it has become recognized that this definition takes no account of the different effects of the various forms of fibre on gastrointestinal function (Eastwood, 1986), and the question has been raised as to whether other components of the diet might also be important in controlling the physiological activity of the intestine in a similar way to materials classically regarded as dietary fibre. For example, resistant starch (Berry, 1984) and proteins (Saunders \& Betschart, 1980) are known to exist in foods and may serve as substrates for the colonic microflora.

The effects of materials currently classed as dietary fibre, on intestinal growth and function, have been the subject of a great deal of research but relatively little is known about the effects of other major components of the diet, particularly in relation to variation in the source rather than dietary concentration. One study performed by Younoszai et al. (1978) investigated the possible effects of feeding diets containing different types of protein, carbohydrate and fat on the growth of the gastrointestinal tract in rats, and it was reported that the dietary protein source (casein or soya-bean protein) was without effect on intestinal growth. In several studies performed in our laboratory, however, it was noted that two proteins (albumin and casein), commonly used in the preparation of semi-synthetic diets, appeared to influence gastrointestinal growth in rats to different extents. Furthermore, the response of the intestine to the addition of guar gum to the diet also appeared to be dependent on dietary protein source. The present study was undertaken to quantify these observed differences in response in rapidly growing rats given a nutritionally adequate diet containing either casein or egg-albumin.

Another important aim of the study was to investigate circulating levels of the gastrointestinal hormone enteroglucagon (EG) in rats given guar gum, and to determine whether this is influenced by dietary protein source. The function of EG is not fully understood but there is evidence that it may act as a mucosal growth-regulating factor (Sagor et al. 1982). It was postulated, therefore, that differences in intestinal growth between dietary groups might be associated with changes in the concentration of circulating EG. 
Table 1. Composition of semi-synthetic diets $(\mathrm{g} / \mathrm{kg}$ diet $)$

\begin{tabular}{lcc}
\hline & Fibre-free diet & Guar-gum diet \\
\hline Albumin or casein* & 168 & 168 \\
Sucrose & 346 & $308 \cdot 5$ \\
Starch & 346 & $308 \cdot 5$ \\
Maize oil & 80 & 80 \\
Minerals & 4 & 40 \\
Vitamin mix & 20 & 20 \\
Guar gum & - & 75 \\
\hline
\end{tabular}

* Casein diets supplemented with $2.5 \mathrm{~g}$ D-methionine $/ \mathrm{kg}$ diet.

$\dagger$ Minerals (g/kg diet): $\mathrm{CaHPO}_{4} 13 \cdot 00, \mathrm{CaCO}_{3} 8 \cdot 20, \mathrm{KCl} 7 \cdot 03, \mathrm{Na}_{2} \mathrm{HPO}_{4} 7 \cdot 40, \mathrm{MgSO}_{4} \cdot \mathrm{H}_{2} \mathrm{O} 4 \cdot 00, \mathrm{MnSO}_{4} \cdot \mathrm{H}_{2} \mathrm{O}$ $0 \cdot 18, \mathrm{ZnCO}_{3} 0 \cdot 10, \mathrm{FeSO}_{4} .7 \mathrm{H}_{2} \mathrm{O} 0 \cdot 144, \mathrm{CuSO}_{4} 0 \cdot 015, \mathrm{KIO}_{3} 0 \cdot 001$.

$\ddagger$ Vitamin mix (mg/kg diet): nicotinic acid 60, cyanocobalamin in manitol 50 , calcium D-pantothenate 40 , thiamin hydrochloride 10 , riboflavin 10 , pteroylmonoglutamic acid 5, D-biotin 1, menadione 1, Rovimix E-25 (Roche) 300, Rovimix A-500 (Roche) 25, Rovimix A-500/D3 (Roche) 15, choline bitartrate 1800 .

\section{MATERIALS AND METHODS}

\section{Animals}

Expt 1. Immature male Wistar rats, weighing approximately $100 \mathrm{~g}$, were randomly divided into four groups of eight and caged individually. The first and second groups received a powdered semi-synthetic diet containing casein (30 mesh, edible casein; G. Fiske \& Co. Ltd, Richmond, Surrey) as the protein source (casein group). The diet given to the first group was fibre-free, whilst that given to the second group contained 75 g guar gum (Sigma, Poole, Dorset) / $\mathrm{kg}$ diet, which replaced equivalent amounts of starch and sucrose (casein-guar gum group). The third and fourth groups received similar diets but with albumin (pasteurized egg albumin; G. Fiske \& Co. Ltd) as the protein source (albumin and albumin-guar gum groups respectively). The compositions of the diets are shown in Table 1. Food and tap water were provided $a d$ lib. Food intakes were measured daily and body-weights recorded weekly for 2 weeks, after which animals were killed. These rats were designated the $14 \mathrm{~d}$ groups.

Expt 2. Having determined from the first study that protein source alone and in combination with guar gum, influenced physiological response to the diet, a second experiment was performed to investigate the effect further by extending both the feeling period and the range of measurements. Rats in this experiment were grouped and nuentained as for rats in Expt 1 except that the feeding period was 3 weeks. These rats were designated the $21 \mathrm{~d}$ groups.

\section{Experimental}

Small intestinal length, and plasma glucagon and EG concentrations, were measured in groups of eight rats after $14 \mathrm{~d}$ on the experimental diets. In addition, the $\mathrm{pH}$ of ileal and caecal contents, and the weights of caecal tissue and contents, were measured in similar groups of rats after $21 \mathrm{~d}$ on the diets, as an indication of possible differences in the amount, and fermentability, of residual material reaching the distal intestine.

The animals were anaesthetized by intraperitoneal injection of sodium pentobarbital (160 mg/ml; $1 \mathrm{ml} / \mathrm{kg}$ body-weight) and killed by cervical dislocation. The abdomen was opened and approximately $2.5 \mathrm{ml}$ of blood collected from the vena cava for determination of plasma glucagon and EG concentration. The small intestine was removed from the rats which had been maintained on the diets for $14 \mathrm{~d}$ and the length was recorded. For the rats which had been maintained on the diets for $21 \mathrm{~d}$, the caecum was ligatured to prevent 
leakage of contents, and the small intestine was removed. The small intestine length was recorded, the ileal contents gently squeezed out with forceps into a plastic vial and the $\mathrm{pH}$ of the contents measured with a micro-electrode. Total caecal weight was then recorded and the $\mathrm{pH}$ of the contents measured by inserting a micro-electrode into an incision in the caecal wall. Caecal contents were removed for determination of the wet:dry weight ratio, and the caecal tissue was rinsed, blotted dry and weighed.

\section{Biochemical analysis}

\section{Plasma glucagon and EG}

Samples of blood $(2.5 \mathrm{ml})$ in heparinized tubes were centrifuged at $2000 \mathrm{~g}$ for $5 \mathrm{~min}$. Plasma ( $1 \mathrm{ml}$ ) was added to aprotinin (Sigma; 2 units in $10 \mu \mathrm{l}$ ) and heparin (Sigma; $70 \mu \mathrm{g}$ in $0.03 \mathrm{ml}$ ), mixed and stored at $-20^{\circ}$ before extraction with ethanol (BDH Analar, $950 \mathrm{ml} / 1 ; 1.8 \mathrm{ml})$. Samples were centrifuged $(2000 \mathrm{~g}$ for $5 \mathrm{~min}$ ) and supernatant fractions removed to fresh glass tubes. The solvent was evaporated on a vortex evaporator at $40^{\circ}$, and the residual material redissolved in a buffered solution $(\mathrm{pH} \mathrm{7.3-7.5)}$ containing $(\mathrm{g})$ $\mathrm{Na}_{2} \mathrm{HPO}_{4} .2 \mathrm{H}_{2} \mathrm{O} 5 \cdot 77, \mathrm{NaH}_{2} \mathrm{PO}_{4} . \mathrm{H}_{2} \mathrm{O} 1 \cdot 05$, human albumin $1 \cdot 00, \mathrm{C}_{2} \mathrm{H}_{5} \mathrm{HgSC}_{6} \mathrm{H}_{4} \mathrm{COONa}$ $0.24, \mathrm{NaCl} 6.0$, aprotinin $40 \mathrm{mg}$ and distilled water to $1000 \mathrm{ml}$, and stored at $-20^{\circ}$ before analysis.

Glucagon and EG were determined by a radioimmunoassay method (Nova Lab. Ltd, Basingstoke, Hants). Kits contained either anti-porcine-glucagon serum, reacting with both glucagon and EG, or an antiserum specific for glucagon. EG concentrations were determined by difference, and expressed as $\mathrm{ng} / \mathrm{ml}$ plasma.

Wet:dry weight ratio. After determination of the total weight of caecal contents, weighed samples were dried in an oven at $85^{\circ}$ for $18 \mathrm{~h}$ and reweighed. The wet: dry weight ratio was calculated and the total dry weight of the caecal contents determined.

\section{Statistical analysis}

Two-way analysis of variance was performed using the statistical package GENSTAT (Alvey et al. 1977), looking at the effect of dietary protein source and guar gum, and possible interactions between these two factors. Least significant differences (LSD), at $P<0.05$ for $28 \mathrm{df}$, were then calculated in those instances where an interactive effect was shown. These values facilitate interpretation of the results when two-way analysis of variance indicates a significant interaction, but a non-significant effect of one of the variables.

\section{RESULTS}

Food intake, and hence growth rate, were depressed by the addition of $75 \mathrm{~g}$ guar gum $/ \mathrm{kg}$ to the diet. Rats receiving the fibre-free casein diet had a significantly higher total food intake over a $14 \mathrm{~d}$ feeding period compared with the other three groups, but the bodyweight gain of this group was not significantly different from those fed on the fibre-free albumin diet (Table 2). Total food intakes of rats consuming the fibre-free casein or albumin diets for $21 \mathrm{~d}$ were similar but the body-weight gain of the albumin-fed animals was significantly greater than that of their casein-fed counterparts. Statistical comparison of food conversion efficiencies (body-weight gain $(\mathrm{g}) \times 100 /$ food intake $(\mathrm{g})$ ), however, showed no differences between mean values for these groups (Table 2).

As expected, the small intestinal length was much greater in those animals consuming guar gum diets. In each study the small intestinal length of rats given the albumin-guar gum diet was higher than that for animals fed on the casein-guar gum diet, but the difference did not reach significance (Table 2). 


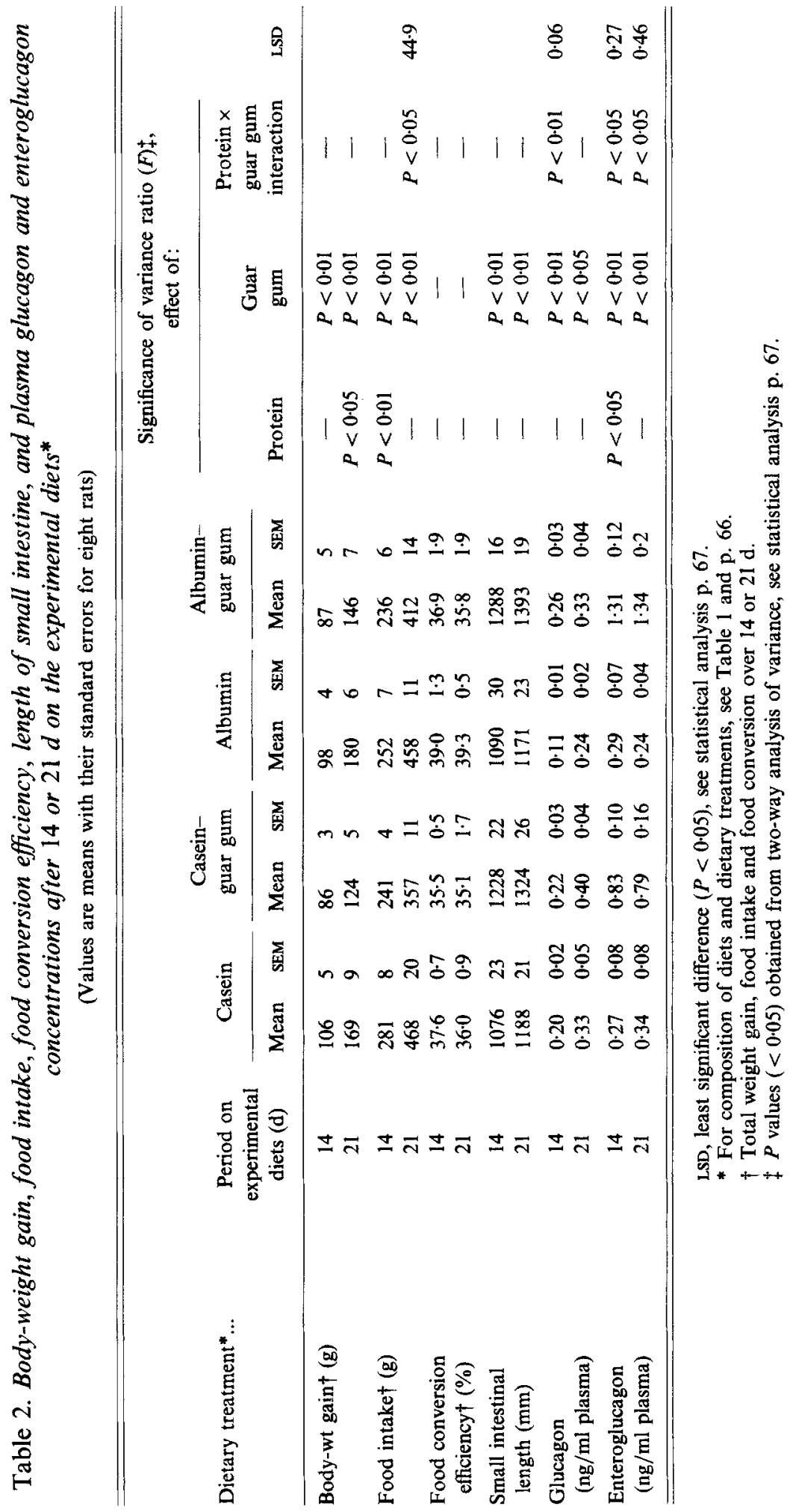




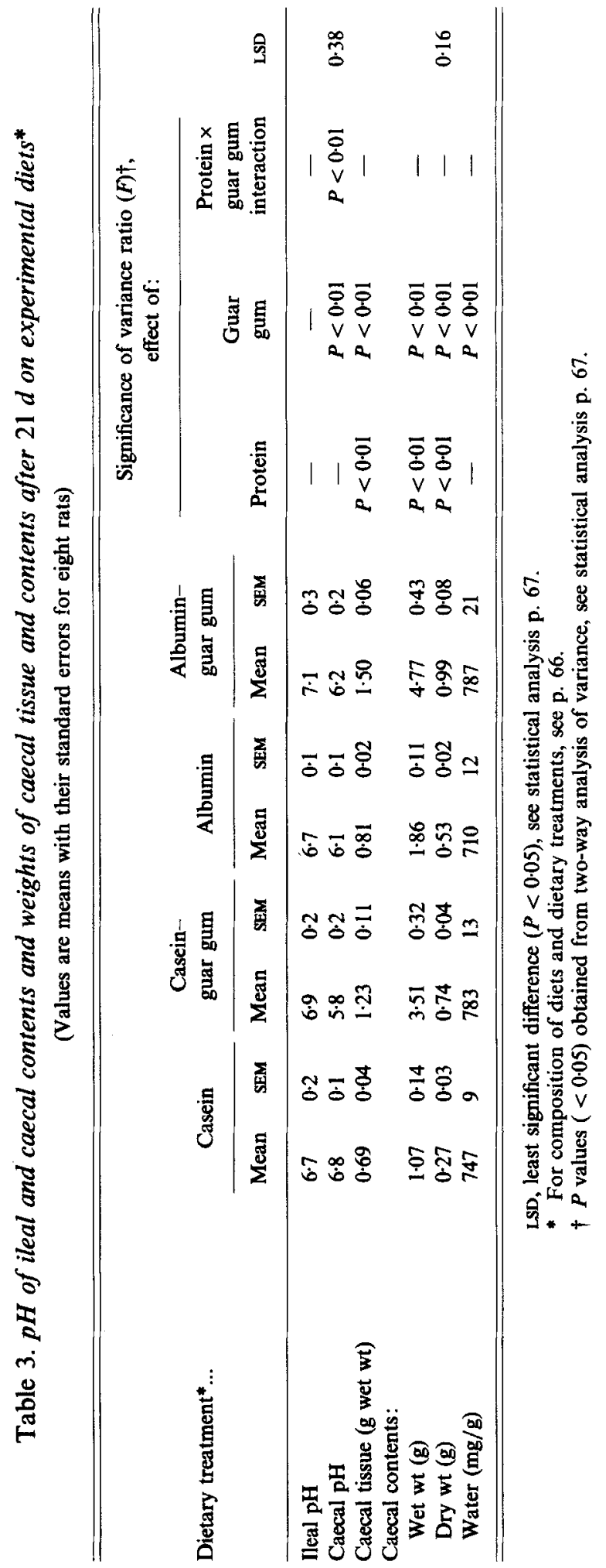


Glucagon and EG concentrations within groups were similar whether the animals were maintained on the diets for 14 or $21 \mathrm{~d}$. In both studies plasma EG concentration was markedly increased in those rats given diets containing guar gum, with a significant interactive effect of albumin and guar gum. EG levels in both the 14 and $21 \mathrm{~d}$ albumin guar gum groups were more than $60 \%$ higher than their casein-fed counterparts (Table 2). Glucagon concentration in the $14 \mathrm{~d}$, but not the $21 \mathrm{~d}$, albumin group was significantly lower than the value for the casein-fed animals. Mean values for both guar gum groups, however, were similar (Table 2).

The $\mathrm{pH}$ of ileal contents was similar in all groups, but there were differences in caecal $\mathrm{pH}$. The pH of the caecal contents of casein-guar-gum-fed rats was significantly lower than that of rats given the fibre-free casein diet. However, this difference was not observed in rats given the albumin diets, both the albumin and albumin-guar gum groups having similar mean caecal $\mathrm{pH}$ values to that of the casein-guar gum group (Table 3).

Weights of caecal tissue, caecal contents (both wet and dry) and water associated with the contents were all increased when guar gum was added to the diet. The largest increases were observed in the albumin-guar-gum-fed rats, which had a significantly greater weight of caecal contents than those rats given a similar diet with casein as the protein source. Albumin alone had a similar effect, with the weights of caecal tissue and contents being higher in the albumin group compared with the casein group (Table 3).

\section{DISCUSSION}

The non-absorbable materials in the human diet consist mainly of polysaccharides which resist hydrolysis by mammalian digestive enzymes and are classed as dietary fibre (Southgate et al. 1978). Broadly, the effect of these materials is to alter the physical properties of the intra-lumen contents throughout the gastrointestinal tract, and hence modify the rate of absorption of nutrients in the small intestine (Blackburn et al. 1984) and the texture and volume of faecal material in the colon (Burkitt et al. 1972). It has occasionally been suggested that other food constituents, which are normally regarded as readily available nutrients, may in some circumstances escape digestion and thereby exert effects similar to those of dietary fibre (Eastwood, 1986). In the present study, dietary protein source influenced both the morphology of the large intestine and the production of faeces. Animals given the fibre-free albumin diet produced poorly formed stools and had a greater mass of both caecal tissue and contents compared with animals given a similar diet with casein as the protein source. It is possible therefore that albumin was less-readily digested and absorbed than casein, or that it limited the absorption of other nutrients in the small intestine. Estimates of the efficiency of food utilization, however, indicated that the weight gain of the albumin-fed rats was as good as that of the casein-fed animals per unit food consumed. It appears, therefore, that if any malabsorption did occur, the residual material which reached the caecum of the albumin-fed rats was utilized and made available to the body by the large bowel microflora.

The precise explanation for these differences between diets, which differed only in their protein content, cannot be determined from the present study but it seems probable that they reflect differences in the pattern of protein digestion. Since a large proportion of protein is absorbed as intact peptides, the rate and extent of protein absorption may depend on the structure of the peptides produced by intralumen digestion, and this will differ between proteins (Silk et al. 1980). An interesting alternative explanation may lie in the possibility that such peptides exhibit hormone-like activity because of their similarity to the endogenous hormones of the gastrointestinal tract (Zioudrou et al. 1979). For example, peptides derived from casein have been shown to alter intestinal motility (Morley et al. 1983). It is 
conceivable, though unproven, that this may in turn influence the rate and extent of nutrient absorption.

In both the casein- and albumin-fed rats, the addition of guar gum to the diet was associated with increased caecal contents, and an increased mass of caecal tissue. The weight of caecal contents in the albumin-guar gum group was significantly greater than in any other group, which again would suggest that in these animals larger quantities of material escaped absorption in the small intestine. It was also found that in the casein-fed animals the $\mathrm{pH}$ of the caecal contents was reduced in the group given guar gum, compared with the fibre-free controls. This change in $\mathrm{pH}$ most likely results from an increase in the metabolic activity of the large bowel microflora, producing alterations in volatile fatty acid (VFA) profile, VFAs yielding the major anions in large bowel contents (Thomson et al. 1982). This difference between groups was not observed in the albumin-fed rats where both the fibre-free and guar gum groups had a similar low caecal $\mathrm{pH}$.

A secondary aim of the present study was to investigate circulating levels of the gastrointestinal peptide EG in rats given guar gum, and to look for any evidence of an effect of protein source. EG is a generic term for a class of peptides produced in the gastrointestinal tract which, though differing in molecular weight, all possess the complete amino acid sequence of pancreatic glucagon. The gastrointestinal peptide is produced by specialized mucosal cells, which have a low density in the jejunum but increase in frequency distally, to reach maximum levels in the ileum. Significant quantities of EG are also found in caecal and colonic tissue. Release of EG follows the ingestion of food, the primary stimulus being intralumen nutrients, particularly sugars and lipids (Jian et al. 1981). Circumstances in which EG release is stimulated include experimental resection of the small bowel in animals (Sagor et al. 1982) and malabsorption due to pathological states, or following jejuno-ileal by-pass surgery in man (Bloom, 1980). The function of EG is not fully understood, but there is much evidence to suggest that high levels in the plasma are associated with increased cellular proliferation in the small intestinal mucosa. (Sagor et al. 1982). An increase in circulating EG levels might therefore explain the increased rates of mucosal cell proliferation described in earlier reports (Jacobs, 1983; Johnson et al. 1984; Johnson \& Gee, 1986).

In both the casein- and albumin-fed rats, the addition of guar gum to the diet was associated with significantly higher plasma EG concentrations when compared with the fibre-free control groups, the greatest increase over control values being in the albumin-fed rats. One possible explanation of the effect of guar gum on plasma EG concentration is that by delaying absorption in the small intestine it increases the quantity of nutrients reaching the distal small intestine and the colon where the density of EG-secreting cells is highest (Riecken \& Gregor, 1985). This mechanism is thought to account for the increased levels of EG observed by Uttenthal $e t$ al. (1982) in rats treated with the disaccharidase inhibitor acarbose. However, in the same study these workers reported a reduction in EG levels in rats fed on guar gum. The reason for this lack of agreement with our results remains to be established.

The present study has demonstrated a dietary interaction between guar gum and the protein component of the diet. The mechanism of this interaction is unclear, but it seems probable that guar gum combined with protein in the small intestinal lumen, reducing its digestion and absorption, and making it available for breakdown in the large bowel. The present findings therefore suggest that dietary protein can modify the effects of fibre. Further research in this area will therefore require an awareness of possible dietary interactions, if a complete understanding of the physiological activity of the fibre component of the diet is to be achieved. 


\section{REFERENCES}

Alvey, N. G., Benfield, C. F., Baxter, R. I., Gower, J. C., Krzanowski, W. J., Lane, P. W., Nelder, J. A., Payne, R. W., Phelps, K. M., Rogers, C. E., Ross, G. J. S., Simpson, H. R., Todd, A. D., Tunnicliffe-Wilson, G., Wedderburn, R. W. M., White, R. P. \& Wilkinson, G. N. (1977). The GENSTAT Manual. Oxford: Rothamstead Experimental Station, Numerical Algorithms Group Ltd.

Berry, C. S. (1984). Flour Millers and Bakers Research Association Bulletin No. 6, 236-248.

Blackburn, N. A., Redfern, J. S., Jarjis, H., Holgate, A. M., Hanning, l., Scarpello, J. H. B., Johnson, I. T. \& Read. N. W. (1984). Clinical Science 66, 329-336.

Bloom, S. R. (1980). In Surgical Management of Obesity, pp. 115-123 [J. D. Maxwell, J.-C. Gazat and T. R. Pilkington, editors]. London: Academic Press.

Burkitt, D. P., Walker, A. R. P. \& Painter, N. S. (1972). Lancet ii, 1408-1412.

Eastwood, M. A. (1986). Lancet i, 1487-1488.

Jacobs, L. R. (1983). American Journal of Clinical Nutrition 37, 954-960.

Jian, R., Besterman, H. S., Sarson, D. L., Aymes, C., Hostein, J., Bloom, S. R. \& Ramband, J. C. (1981). Digestive Diseases and Sciences 26, 195-201.

Johnson, I. T. \& Gee, J. M. (1986). British Journal of Nutrition 55, 497-505.

Johnson, I. T., Gee, J. M. \& Mahoney, R. R. (1984). British Journal of Nutrition 52, 477-487.

Morley, J. E., Levine, A. S., Yamada, T. M., Gebhard, R. L., Prigge, W. F., Shafer, R. B., Goetz, F. A. \& Silvis, S. A. (1983). Gastroenterology 84, 1517-1523.

Riecken, E. O. \& Gregor, M. (1985). Scandinavian Journal of Gastroenterology 20, Suppl. 112, $30-40$.

Sagor, G. R, Al-Mukhtar, M. Y. T., Ghatel, M. A., Wright, N. A. \& Bloom, S. R. (1982). British Journal of Surgery 69, 14-18.

Saunders, R. M. \& Betschart, A. A. (1980). American Journal of Clinical Nutrition 33, 960-961.

Silk, D. B. A., Fairclough, P. D., Clark, M. L., Hegarty, J. E., Marrs, T. C., Addison, J. M., Burston, D., Glegg, K. M. \& Matthews, D. M. (1980). Journal of Parenteral and Enteral Nutrition 4, 548-553.

Southgate, D. A. T., Hudson, G. J. \& Englyst, H. (1978). Journal of the Science of Food and Agriculture 29, 979-988.

Thomson, L. L., Tasman-Jones, C., Lee, S. P. \& Robertson, A. M. (1982). In Colon and Nutrition, Falk Symposium no. 32, pp. 47-51 [H. Kasper and H. Goebell, editors]. Lancaster: MTP Press.

Uttenthal, L. O., Harris, A., Yeats, J. C., Ghatei, M. A., Sagor, G. R., Polak, J. M. \& Bloom, S. R. (1982). Diabetalogica 22, 397.

Younoszai, M. K., Adedoyin, M. \& Ranshaw, J. (1978). Journal of Nutrition 108, 341-350.

Zioudrou, C., Streaty, R. A. \& Klee, W. A. (1979). Journal of Biological Chemistry 254, 2446-2449. 